\title{
Terms of Trade, Intermediate Goods and International Real Business Cycles: Australia Case
}

\author{
JaI Hyting YOON ${ }^{*}$ and Francis IN $^{* *}$
}

This paper examines whether a two-sector business cycle model with intermediate and import goods successfully replicates stylized facts of the international real business cycic in a small open economy. Our model incorporates the neoclassical framework, with productivity shocks in both manufacturing and non-manufacturing sectors, terms of trade shock, import goods and intermediate goods. Our model is able to mimic the important features of business cycles in Australia. Ihe proxhertivity shock of the non-manufacturing sector has a dominant role in a small open exonomy's businexs cycle. The productivity shock of the non-manufacturing sector increases imports more than exports.

Keywords: international real business cycle, small open economy, the terms of trade, manufacturing and non-manufacturing sectors, sectoral shocks

- Correspunding author. Direct all correspondence to Jai Hyung Yoon, Economist, POSCO Research ltrstifute. POSRI Bldg., 147, Samsung-dong, Gangnam-gu, Seoul 135-878, Korea; 'I'el: 82-2-3457-8149; E-mail: jhy(a)posri.re.kr

Francis In, Professor, Department of Accounting and Finance Building 11, Monash University, Vic 3800, Australia; Tel: 61-3-9005-1561; L-mail: Francis.In(C)Buscomisnast.edu.au 


\section{INTRODUCTION}

ince the pioneering work initiated by Backus, Kehoe and Kyland (1992), the $\mathcal{O}$ study of international real business cycle models has been growing fast in the last several years and has become one of the most active research areas in the business cycle literature.

Backus, Kehoe and Kyland $(1992,1995)$ ask whether a two-country real business cycle model can account simultaneously for domestic and international aspects of business cycles. Their results indicate that although their models can explain many stylized facts, the quantity anomaly and the price anomaly ${ }^{1}$ are quite robust for the choice of parameter values and even to the perturbations of the model structure. Zimmermann (1999) introduces exogenous exchange rate movements in addition to standard technological shocks, and his model comes much closer to replicating the relatively high volatility observed in the data, but it cannot solve the quantity anomaly. To mimic the volatile real exchange rate, Mendoza (1991a, 1991b and 1995) introduces exogenous world interest rate shock and/or the terms of trade shock into his small open economy models.

To replicate the salient (international anomalies) features of the data, some researchers introduce other sources of shocks, like oil shocks (Costello and Praschnick 1993) and taste shocks (Stockman and Tesar 1995). But both of these shocks turn out to have little effect on cross-country correlations and the variability of trade-related variables. Devereux, Gregory and Smith (1992) develop a model with a particular type of non-separability between consumption and leisure. They succeed in lowering the cross-country correlation of consumption, by modifying the specification of an agents' preference. Canova and Lbide (1997) develop a two-country model with home production. Their results indicate that an international business cycle model with household production can better match cross-country output, consumption and labor correlations.

A few papers build international business cycle models with intermediate inputs (See Costello and Praschnick 1993, Head 1997 and Kouparitsas 1995). Costello and Praschnick (1993) develop a two-country model which predicts a higher cross correlation of output than Backus, Kehoe and Kyland (1995). Head (1997) builds a two-country model with differentiated intermediate goods and shows that increasing returns to the variety of intermediate goods can lead to a positive international transmission of the business cyclc. Kouparitsas (1995) introduces production interdependence via intermediate inputs. In his two-country model, primary products are used as an intermediate input in the produrtion of manufactured goods, and the North imports primary products from the South in exchange for exports of manufactured goods.

Recently, Ambler, Cardia and Zimmermann (forthcoming) built a two-country, multi-sector model to examine the role of sectoral shocks and intermediate goods trade in the international propagation of the business cycle. Whalley (1995) reports that the share of trade in intermediate goods is larger than the share of trade in final goods. For example, crade in intermediate gouds represents approximately $60 \%$ 
of cotal trade. Given its quantitative importance in the data, Ambler, Cardia and Zimmermann (forthcoming) argue that introducing trade in intermediate goods in multi-country models could significantly affect their ability to explain the main features of the intertemporal transmission of the business cycle.

In our paper, we build a small open economy, multi-sector model to examine the effects of sectoral shocks and the terms of trade shocks in the international transmission mechanism of the business cycle. Our model has at least three salient features. First, in contrast to the model developed by Ambler, Cardia and Zimmermann (forthcoming), which is a two-country international real business cycle model with two sectors that can be solved by the linear quadratic approximation method, our model is a one-country model with two sectors. A two-country model is based on the rclation either between large countries or groups of countries, whereas our model is based on a small open economy, thereby treating the shock from overseas as an exogenous variable.

Second, our model has incorporated import goods, which can be used for production as input factors. Impore goods as input factors imply that the terms of trade shock affect macroeconomic variables through sectoral goods production and marginal productivity of sectoral goods production. For example, the terms of trade shock decrease the relative price of import goods, and thus increase imports. ${ }^{2}$ The increased imports raise the marginal productivities of capital, labor supply and intermediates, and then increase sectoral productions, and thus GDP, consumption and investment. This procedure shows a different mechanism from the substitution of consumption and investment to imports in a one-sector model.

Third, we incorporate two sectoral productivity shocks in our model. Two sectoral shocks affect macroeconomic variables through the changes of sectoral productivities. The effects of two sectoral productivity shocks are different in magnitude and dinections. By incorporating two sectoral productivity shocks, we analyze which sector of manufacturing and non-manufacturing sector impacts more strongly on economic fluctuations.

Our model can solve the quantity anomaly to a considerable extent. Moreover, we found out that the non-manufacturing industry is a dominant sector in the Australian business fluctuation. Moreover, technology change in manufacturing production has a weaker effect on Australian business fluctuations than technology shock of foreign sector, which is reflected in terms of trade shocks.

This paper is oryanized as follows: Section II provides a full description of the dynamic stochastic model of a small open economy. Section III shows the conditions for optimal allocation of the dynamic programming problem. Section IV provides the key fundings as well as sensitivity analysis and impulse response analysis. Finally, concluding remarks are presented in Section V.

\section{AN INTERNATIONAL REAL BUSINESS CYCLE MODEL WITH TWO SECTORS}

A dynamic stochastic model of a small open economy is developed to investigate 
the shock effects of manufacturing and non-manufacturing sectors and terms of trade. The structure of the model is a streamline version of the model used by Ambler, Cardia and 7immermann (forthoming) and Mendoza (1991 a). Our model cannot analyze the spillover effects of productivity shocks from one country to the other country differently from Ambler, Cardia and Zimmermann (forthcoming). However, we incorporate the terms of trade into our model, and thus we can analyze that productivity shocks of foreign sector have effects on the domestic sector.

\section{Preferences}

Agents of infinite life having identical preferences allocate $C_{4}$ (private consumption) and $N_{t}$ (labor supply) intertemporarily to maximize utility.

$$
\mathrm{V}=\mathrm{E}\left[\sum_{1=0}^{\infty} \beta^{\mathrm{c}} \mathrm{U}\left\{\mathrm{C}_{1}, N_{1}\right\}\right]
$$

The instantancous utility function and time-preference functions arc as follows:

$$
\begin{gathered}
\mathrm{U}(\cdot)=-\frac{\left[\mathrm{C}_{\mathrm{t}}-\frac{\mathrm{N}_{\mathrm{t}}^{1+\hat{\theta}}}{1+\theta}\right]^{1-\gamma}-1}{\frac{1-\gamma}{1-\gamma}}-\infty(\cdot)<0, \mathrm{U}^{\prime}(\cdot)>0, \mathrm{U}^{\prime}(0)=\infty, 1+0>\mathrm{I}, \gamma>\mathrm{I}
\end{gathered}
$$

The parameter $\beta$ is the rate of time preference. The parameter $\theta$ is the elasticity of substitution between consumption and labor supply. The coefficient $y$ indicates relative risk aversion. The intertemporal discount rate equalizes to the world's real interest rate according to the accumulation of foreign financial assets.

\section{Sectoral Production and Technology}

The sectoral productions are given by Cobb-Douglas production function using capital, labor, intermediate goods and import goods.

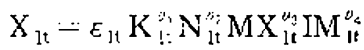

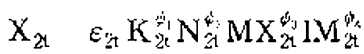

where $\sum y_{j}=1, \sum \phi_{i}=1$ and $\mathrm{X}_{1 \mathrm{c}}$ and $\mathrm{X}_{2 \mathrm{t}}$ are sectoral outputs, respectively. Kit and Nit are the capital stock and labor supply used in sector $i$, respectively. MXi indicates the intermediate goods which are used to produce sectoral good i. $\nu_{1}$ and $\psi_{1}$ are referred to as the shares of input factors for production in two sectors. Sectoral productions are dependent on the sectoral technology shocks $\varepsilon_{1 t}$ and $\varepsilon_{2 t}$ as well as the input factors. The sectoral technology shocks, $\varepsilon_{11}$ and $\varepsilon_{2 t}$, follow the first-order Markov distribution function. 


\section{Intermediate Goods Production}

Intermediate goods producers aggregate sectoral good to produce intermediate goods. The intermediate goods are used to produce sectoral goods.

$$
\mathrm{MX}_{\mathrm{t}} \cdot\left[\omega \mathrm{F}_{1 \mathrm{l}}^{1-\rho}+(1-\omega) \mathrm{F}_{2 t}^{1-o}\right]^{\frac{1}{1-\rho}}
$$

where $F_{16}$ and $F_{21}$ are the arnounts of $X_{16}$ and $X_{31}$ to ptoduce intermediate goods $\mathrm{MX}_{t}$, respectively. $\omega$ implies the contribution degree of sector 1 goods in intermediate good production $\rho$ indicates the substitution elasticity between sectoral goods. The produced intermediate goods are distributed in $\mathrm{MX}_{\mathrm{t}}=\sum_{i=1}^{2} \mathrm{MX}$ it and used for the production of sectoral goods.

\section{Final Good Production}

Final goods producers aggregate sectoral goods to produce final goods, ${ }^{3}$ which are used for consumption, investment and exports.

$$
Y_{t}=\left[\pi Q_{1 t}^{1-i}-(1-\pi) Q_{2}^{1-\lambda}\right]^{\frac{1}{1-i}}
$$

where $\mathrm{Q}_{\mathrm{t}}$ is the amount of $\mathrm{X}_{\mathrm{it}}$ used to produce final good $\mathrm{Yt}$. The final goods aggregator $(\lambda)$ shows the substitution elasticity between sectoral goods. $\pi$ represents the share of sector 1 goods in the final goods production. The final goods producer allocates the sectoral goods for profit maximization.

\section{Capital Accumulation, Trade Balance and Financial Structure}

The law of motion for the capital srock is as follows:

$$
\mathrm{K}_{\mathrm{it}+\mathrm{l}}=\mathrm{K}_{\mathrm{i}:}\left(1-\delta_{i}\right)+\mathrm{I}_{\mathrm{it}} \quad \mathrm{i}=1,2
$$

where lit denotes sectoral investment, and $\delta_{2}$ is a constant sectoral rate of depreciation. It assumes that capital stock docs not move between sectors.

The financial structure is linked with trade balance. 4 Financial structure assumes that an agent in the economy is a small participant and this representative agent has access to world capital markets to borrow and lend foreign financial assets $\left(A_{r}\right)$. Holdings of foreign financial assets $\left(A_{:+1}\right)$ evolve according to:

$$
\begin{gathered}
P_{d, t} E_{t}-P_{m, t} I M_{t}=P_{m, t} A_{t+1}-\left(1-r^{*}\right) P_{m, t} A_{t} \\
\varepsilon_{3 t} p L X_{t}-I M_{t}-A_{t+1}-\left(1+I^{*}\right) A_{t}
\end{gathered}
$$


where, $\varepsilon_{3 t} p=\frac{P_{t, t}}{P_{n, t}}, P_{d, t}$ and $P_{m, t}$ are export prices and import prices, respectively. EXt is exports; IMt is imports; $r^{*}$ is the exogenously determined world's real interest rate; $\varepsilon_{31}$ is the terms of trade shock; and $p$ is the relative price of exports to imports and is assumed as one.

\section{Resource Constraint}

Finally, the model completes with a resource constraints as follows:

$$
\begin{aligned}
& \varepsilon_{3 t} \mathrm{pC}_{\mathrm{t}}+\mathrm{K}_{1 \mathrm{t}+1}-\left(1-\delta_{1}\right) \mathrm{K}_{1 \mathrm{t}}+\mathrm{K}_{2 \mathrm{t}+1}-\left(1-\delta_{2}\right) \mathrm{K}_{2 t}+\mathrm{IM}_{\mathrm{t}}+\mathrm{A}_{\mathrm{t}+1}-\left(1+\mathrm{r}^{*}\right) \mathrm{A}_{1} \\
& <\varepsilon_{i t} \mathrm{pY_{1 }}-\frac{\phi_{1}\left(\mathrm{~K}_{1 \mathrm{t}+1}-\mathrm{K}_{1 \mathrm{t}}\right)}{\mathrm{K}_{\mathrm{tt}}} \cdot \frac{\phi_{2}\left(\mathrm{~K}_{2 t-1}-\mathrm{K}_{2 t}\right)}{\mathrm{K}_{2 t}}
\end{aligned}
$$

wherc $\phi_{1}$ and $\phi_{2}$ are parameters to restrict the adjustment costs. The aggregate resource constraint ${ }^{6}$ of the economy indicatcs that the sum of consumption, investment, and exports cannot be exceeded by the final goods production.

\section{DYNAMIC PROGRAMMING PROBLEM, SOLUTION TECHNIQUUE AND PARAMETER CALIBRATIONS}

\section{Solving Dynamic Programming Problems}

The social planner selects paths of cunsumption and labor supply to maximize the whole life-time utility. To solve the dynamic progranming problem, the household's optimal intertemporal decisions are to choose the control variables $\left(\mathrm{C}_{t}, \mathrm{~K}_{1 t+1}, \mathrm{~K}_{? t-1}\right.$, $A_{1: 1}, N_{11}, N_{2 i}, M_{11}, M X_{21}, I_{16}, I_{21}, Q_{11}, Q_{2 t}, F_{11}, F_{2 t}$ ) in period $t$, given the state of the economy as described by $\left(\mathrm{K}_{1 \mathrm{t}}, \mathrm{K}_{2 \mathrm{t}}, \mathrm{A}_{1}, \varepsilon_{1 \mathrm{t}}, \varepsilon_{2 \mathrm{t}}\right.$ and $\left.\varepsilon_{3 \mathrm{t}}\right)$. To solve the dynamic programming problem, the lagrangian problem is built as follows:

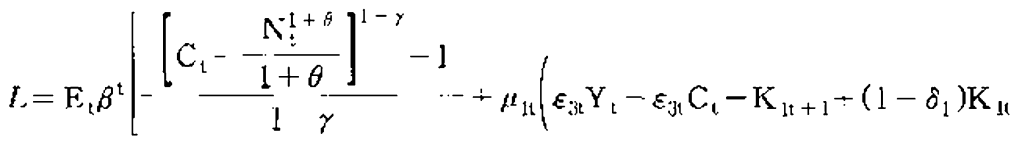

$$
\begin{aligned}
& -\mathrm{K}_{2 t+1}-\left(1-\delta_{2}\right) \mathrm{K}_{2 t}-\mathrm{M}_{\mathrm{t}}-\mathrm{A}_{\mathrm{t}+1}+\left(1-\mathrm{r}^{*}\right) \mathrm{A}_{1} \\
& \left.-\frac{\phi_{1}\left(\mathrm{~K}_{1 \mathrm{t}: 1}-\mathrm{K}_{1 \mathrm{t}}\right)^{2}}{\mathrm{~K}_{\mathrm{tt}}}-\frac{\phi_{2}\left(\mathrm{~K}_{2 \mathrm{t}+1}-\mathrm{K}_{2 \mathrm{t}}\right)^{2}}{\mathrm{~K}_{2 t}}\right)+\mu_{2 t}\left(\mathrm{X}_{1 \mathrm{t}}-\mathrm{Q}_{1 \mathrm{t}}-\mathrm{r}_{1 \mathrm{t}}\right) \\
& \left.+\mu_{3 t}\left(\mathrm{X}_{2 t}-Q_{2 t}-\mathrm{F}_{\mathrm{Yt}}\right)+\mu_{4 t}\left(\left[\omega \mathrm{F}_{11}^{\mathrm{k}-\rho}+(1-\omega) \mathrm{F}_{2 \mathrm{t}}^{1-\rho}\right]^{\frac{1}{1-\rho}}-\mathrm{MX}_{1 \mathrm{t}}-\mathrm{MX}_{2 \mathrm{t}}\right)\right]
\end{aligned}
$$

The first-order conditions for utility maximization are: 


$$
\begin{aligned}
& \left(C_{\mathrm{t}}\right):\left[\mathrm{C}_{\mathrm{t}}-\frac{\mathrm{N}_{1}^{1+\theta}}{1+\theta}\right]^{-\gamma}=\mu_{1 \mathrm{t}} \bar{c}_{3 \mathrm{t}} \\
& \left(\mathrm{K}_{\mathrm{t}+\mathrm{l}}\right): \mu_{\mathrm{lt}}\left(1+-\frac{\phi_{1}\left(\mathrm{~K}_{\mathrm{it}+1}-\mathrm{K}_{\mathrm{lt}}\right)}{\mathrm{K}_{1 \mathrm{t}}}\right)=\beta \mu_{3 \mathrm{t}+1}\left(v_{1} \frac{\mathrm{X}_{\mathrm{lt}+1}}{\mathrm{~K}_{\mathrm{tt}-1}}\right) \\
& -\beta \mu_{\mathrm{lt}-1}\left(\left(1-\delta_{1}\right)+\frac{2 \phi_{\mathrm{l}}\left(\mathrm{K}_{\mathrm{lt}-2}-\mathrm{K}_{\mathrm{lt}+1}\right)}{\mathrm{K}_{\mathrm{lt}+1}}+-\frac{\phi_{1}\left(\mathrm{~K}_{\mathrm{lt}+2}-\mathrm{K}_{1++1}\right)^{2}}{\mathrm{~K}_{1++1}}\right)
\end{aligned}
$$

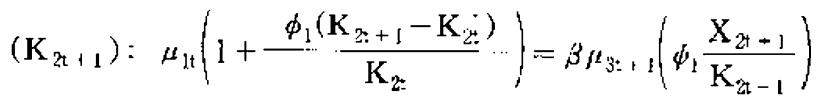

$$
\begin{aligned}
& -\beta \mu_{\mathrm{tt}-1}\left(\left(1-\delta_{2}\right)+\frac{2 \phi_{2}\left(\mathrm{~K}_{2 \mathrm{t}+2}\right.}{\mathrm{K}_{2 t+1}}-\frac{\left.\mathrm{K}_{2 \mathrm{t}+1}\right)}{\cdot \phi_{2}\left(\mathbf{K}_{2 t+2}-\mathbf{K}_{2 t+1}\right)^{2}} \mathrm{~K}_{2 \mathrm{t}+1}\right) \\
& \left(N_{1 t}\right): \mu_{11} \varepsilon_{3 t} N^{8}=\mu_{2 t}\left(v_{2} \frac{X_{3 t}}{N_{1 t}}\right) \\
& \left(\mathrm{N}_{2 \mathrm{t}}\right): \mu_{\mathrm{lt}} \varepsilon_{3 \mathrm{t}} \mathrm{N}_{t}^{\theta}=\mu_{3 \mathrm{t}}\left(\psi_{2} \frac{\mathrm{X}_{2 \mathrm{t}}}{\mathrm{N}_{2 \mathrm{t}}}\right) \\
& \left(\mathrm{MX}_{1 \mathrm{t}}\right): \mu_{2 \mathrm{t}} \nu_{3} \frac{\mathrm{X}_{1 \mathrm{t}}}{\mathrm{MX}_{1:}}=\mu_{4 \mathrm{t}} \\
& \left(\mathrm{MX}_{2 \mathrm{t}}\right): \mu_{3 \mathrm{t}} \phi_{3 \mathrm{3}} \frac{\mathrm{X}_{2 t}}{\mathrm{MX}_{\pi}}=\mu_{4 \mathrm{t}} \\
& \left(\mathrm{IM}_{\mathrm{lt}}\right): \mu_{\mathrm{zt}} v_{4} \frac{\mathrm{X}_{\mathrm{lt}}}{\mathrm{IM}_{1 \mathrm{t}}}-\mu_{\mathrm{it}} \\
& \left(\mathrm{IM}_{\lambda t}\right): \mu_{31} \psi_{4} \frac{\mathrm{X}_{2 t}}{\mathrm{MX}_{2 t}}=\mu_{1 \mathrm{t}} \\
& \left(Q_{1 \mathrm{t}}\right): \mu_{11} \varepsilon_{3 \mathrm{l}}\left[\pi \mathrm{Q}_{1 \mathrm{t}}^{1-\lambda}+(1-\pi) \mathrm{Q}_{2 \mathrm{t}}^{1-\lambda}\right]^{\frac{\lambda}{1-\lambda}} \pi \mathrm{Q}_{1:}^{-\lambda}=\mu_{2 \mathrm{t}} \\
& \left(Q_{2 t}\right): \mu_{1 \mathrm{t}} \epsilon_{3 \mathrm{t}}\left[\pi Q_{1 \mathrm{l}}^{1}+(1-\pi) Q_{2 \mathrm{l}}^{1}\right]^{i} \mathrm{i}^{i} \lambda(1-\pi) Q_{2 \mathrm{t}}^{-i}=\mu_{3 t} \\
& \left(\mathrm{~F}_{11}\right): \mu_{4 t}\left[\omega \mathrm{F}_{\mathrm{lt}}^{1}+(1 \quad \omega) \mathrm{F}_{2 \mathrm{t}}^{1 n \rho}\right]^{\frac{\rho}{1-\rho}} \omega \mathrm{F}_{\mathrm{It}}^{-\rho} \quad \mu_{2 t} \\
& \left(F_{\mathrm{Zt}}\right): \mu_{4 t}\left[\omega \mathrm{F}_{\mathrm{i}}^{1} \rho^{\rho}-(1-\omega) \mathrm{F}_{2 \mathrm{t}}^{1-\rho}\right]^{1^{\rho-\rho}}(1-\omega) \mathrm{F}_{7 \mathrm{t}} \rho=\mu_{3 t} \\
& \left(\mathrm{~A}_{1-1}\right): \mu_{1 \mathrm{t}}=\mu_{\mathrm{tt}+1} \\
& \left(\mu_{1 \mathrm{t}}\right): \varepsilon_{3 \mathrm{t}}\left[\pi_{1} \mathrm{Q}_{1 \mathrm{t}}^{1-\lambda} 1 \pi_{2} \mathrm{Q}_{2 \mathrm{t}}^{1-\lambda}\right]^{\frac{1}{1 \cdots \lambda}}=\varepsilon_{3 \mathrm{t}} \mathrm{C}_{\mathrm{t}}+\mathrm{K}_{1 \mathrm{t}+1}\left(1-\delta_{1}\right) \mathrm{K}_{\mathrm{lt}} \\
& +\mathrm{K}_{2 t+1}-\left(1-\delta_{2}\right) \mathrm{K}_{2 \mathrm{t}}+\mathrm{IM}+\mathrm{A}_{\mathrm{t}+1}-\left(1+\mathrm{r}^{*}\right) \mathrm{A}_{\mathrm{t}} \\
& +\frac{\phi_{1}\left(K_{1 t, 1}-K_{1 t}\right)^{2}}{K_{1 t}}+\frac{\phi_{2}\left(K_{n+1}-K_{2 t}\right)^{2}}{K_{2 t}} \\
& \left(\mu_{2 t}\right): X_{1 t}=Q_{11}+F_{1 t} \\
& \left(\mu_{3 t}\right): X_{3 t}=Q_{z}+F_{2 t} \\
& \left(\mu_{4 \mathrm{t}}\right):\left[\omega \mathrm{F}_{\mathrm{lt}}^{1} \rho+(1-\omega) \mathrm{F}_{2 \mathrm{t}}^{1}\right]^{\frac{1}{1-o}}=\mathrm{MX}_{\mathrm{lt}}+\mathrm{MX}_{24}
\end{aligned}
$$

To solve the dynamic program problem by using the undetennined coefficient method 
(Christiano 1998), we should linearize the first ordes conditions around the steady state values. Then, all control variables and costate variables can be expressed as linear functions of current capital stocks, forcign financial assets and shocks $\left(\mathrm{K}_{\mathrm{r}}\right.$, $\mathrm{K}_{2 \mathrm{t}}$, At, $\varepsilon_{11}, \varepsilon_{2 \mathrm{t}}$ and $\varepsilon_{3 \mathrm{t}}$. We can simulate the model by generating the random shocks.

\section{Calibration}

We use economic theory extensively as the basis for restricting the general framework for finding numerical values for parameters. The relevant parameters of preference are principally taken from Mendoza (1991a) and Ambler, Cardia and Zimmermann (forthcoming). The world real interest rate is set at $4 \%$, which is obtained from Mendoza (1991a), and thus intertemporal discount rate $(\beta)$ is calculated as 0.96 $\left(1 /\left(1+t^{*}\right)\right)$. The patameter of the intertemporal elasticity of substitution in labor supply is set at 0.455 from Mendoza (1991a). The coefficient of relative risk aversion $(\gamma)$ is set to 1.8 .

Tabi.: 1. Bengimark Parami:ter Values

\begin{tabular}{|c|c|c|}
\hline Parameter & Definition & Value \\
\hline$\beta$ & The rate of time pseference & 0.9615 \\
\hline$\%$ & Coefficient of relative risk avcrsion & 1.8 \\
\hline$\theta$ & $\begin{array}{l}\text { Inverse of the intertemporal elasticity of substinution } \\
\text { in tabor supply }\end{array}$ & 0.155 \\
\hline$v_{1}$ & Capital shares in manufacturing production & 0.11 \\
\hline$\psi_{\mathrm{l}}$ & Capital shares in non-manufacturing production & 0.29 \\
\hline$v_{2}$ & Labor shares in manufacturing production & 0.21 \\
\hline$\phi_{2}$ & Labor shares in non-manufacturing production & 0.33 \\
\hline$\nu_{3}$ & Intermediate goods shares in manufacturing production & 0.56 \\
\hline$\psi_{3}$ & Intermediate gonds shares in non-manufacturing production & 0.34 \\
\hline$y_{4}$ & Import gooxds shares in manufacturing production & 0.12 \\
\hline$\psi_{4}$ & Impore gonds shares in non-manufacturing praduction & 0.04 \\
\hline 1ip & Flascicity of substitution in intermediate good production & 0.9 \\
\hline$\omega$ & Manufactured good shares in intermediate good production & 0.43 \\
\hline $1 / \lambda$ & Elasticity of substitution in final good production & 0.9 \\
\hline$\pi$ & Marufaccured good share in final goort prextaction & 0.26 \\
\hline$\delta_{1}$ & Depreciation rate in capital stock of manufacturing sector & 0.12 \\
\hline$\hat{s}_{2}$ & Depreciation sate in capital stock of non-manufacturing sector & 0.08 \\
\hline$\phi_{1}$ & Adjustment costs in manufacturing sector & 1.0 \\
\hline$\phi_{2}$ & Adjustment costs in non-manufacturing sector & 1.0 \\
\hline $\mathrm{r}^{*}$ & World interest rate & 0.04 \\
\hline
\end{tabular}


The relevant parameters of sectoral productions arc calculated from national income data and input-output tables. By using average annual values of input-output tables, capital shares $\left(\nu_{1}\right.$ and $\left.\psi_{1}\right)$ are set at 0.11 and 0.29 , and labor shares ( $y_{2}$, and $\psi_{2}$ ) are calculated as 0.21 and 0.33 in manufacturing and non-manufacturing productions, which means that manufacturing productions are relatively more labor intensive than non-manufacturing productions. Intermediate goods shares $\left(v_{3}\right.$ and $\left.\psi_{3}\right)$ in manufacturing and non-manufacturing productions are set at 0.56 and 0.34 , respeccively. Import goods shares $\left(v_{4}\right.$ and $\left.\psi_{4}\right)$ are 0.12 and 0.04 , respectively. The elasticitics of substitution $(1 / \rho)$ berween sectotal goods in intermediate good production are set as 0.9 , and the elasticity of substitution $(1 / \lambda)$ between sectoral goods in final goods production is also 0.9 obtained from Ambler, Cardia and Zimmermann (forthcoming).

The parameters for intermediate goods production are computed from input-output tables. Sectoral goods shares in intermediate goods production $(\omega$ and $(1-\omega))$ are calculated as average annual values of 0.43 and 0.57 . Sectoral goods shares also in final goods production ( $\pi$ and $(1-\pi)$ ) are set as 0.26 and 0.74 from input-output tables. Depreciation rates $\left(\delta_{1}\right.$ and $\left.\delta_{2}\right)$ are set at 0.12 and $0.08,{ }^{7}$ respectively. Adjustment cost coefficients $\left(\phi_{1}\right.$ and $\left.\phi_{2}\right)$ are set at the same value of 1.0 .

\section{Shock Process}

Parameters of shock process are estimated using secroral gross domestic product (GDP) data, which is filtered by the linear time trend. It is assumed that the shock process follows the first-order Markov distribution function and is estimated by VAR (vector autoregression). The estimation result is as follows:

$$
\left[\begin{array}{l}
\varepsilon_{1 t+1} \\
\varepsilon_{2 t+1} \\
\varepsilon_{31+1}
\end{array}\right]=\left[\begin{array}{rrr}
0.43 & 0.70 & -0.14 \\
-0.09 & 0.88 & 0.02 \\
0.48 & 0.53 & 0.51
\end{array}\right]\left[\begin{array}{l}
\varepsilon_{1 t} \\
\varepsilon_{2 r} \\
\varepsilon_{3 t}
\end{array}\right]+\left[\begin{array}{l}
W_{11+1} \\
W_{3 t+1} \\
W_{3 t+1}
\end{array}\right]
$$

The variance-covariance matrix of the innovation is:

$$
\left[\begin{array}{lll}
0.00074 & 0.00039 & 0.00064 \\
0.00039 & 0.00028 & 0.00026 \\
0.00064 & 0.00026 & 0.00266
\end{array}\right]
$$

and the percentage standard deviations are $2.7,1.7$ and 5.2 respectively. The diagonal terms show the variance of shocks and the terms below the diagonal terms represent the covariance values.

\section{EMPIRICAL FINDINGS}

\section{Business Cycle Properties}

Table 2 represcnts the major featurcs of the real economy and the benchenatk 
economy. The standard deviations of the real data from Table 2 provide that investment, 6.71 , is mure volatile than output, 5.0 , and consumption, 4.46 . The standard deviation of trade balance shows the lowest value at 1.0. The highest standard deviation is shown from foreign financial assets at 15.26. In addition, the standard deviations of imports and investment are fairly high at 8.39 and 6.71 . The standard deviations of the benchmark economy are similar to real data in consumption $(4.46,3.76)$, investment $(6.71,6.83)$ and trade balance $(1.00,1.59)$. In addition, labor supply shows low values $(1.07,2.74)$ even though it is overestimated. The standard deviations of foreign sectors such as imports, interest payments and terms of trade correlate well with the real data in size order even though they are underestimated. In the case of first order serial correlation, the benchmark economy mimics fairly well the real data. For instance, the autocorrelations of consumption are similar at 0.51 and

Table 2. Staticat. Moments: Australiay data and the Benchmark Model

\begin{tabular}{|c|c|c|c|c|c|c|}
\hline \multicolumn{2}{|c|}{ Australian data } & \multicolumn{2}{|l|}{$1965-1999$} & \multicolumn{3}{|c|}{ The benchmark model } \\
\hline & $\sigma_{x}$ & $\rho_{x t, x t} \quad 1$ & $\rho_{x: C D t^{4}}$ & $\sigma_{x}$ & $\rho_{x t, x:-1}$ & $\rho_{x t, \cos t}$ \\
\hline GDP & $\begin{array}{c}5.00 \\
(0.929)\end{array}$ & $\begin{array}{c}0.45 \\
(0.139)\end{array}$ & 10 & $\begin{array}{c}5.00 \\
(0.596)\end{array}$ & $\begin{array}{c}0.45 \\
(0.212)\end{array}$ & 1.0 \\
\hline Consumption & $\begin{array}{c}4.46 \\
(0.912)\end{array}$ & $\begin{array}{c}0.51 \\
(0.138)\end{array}$ & $\begin{array}{c}0.95 \\
(0.022)\end{array}$ & $\begin{array}{c}3.76 \\
(0.455)\end{array}$ & $\begin{array}{c}0.39 \\
(0.218)\end{array}$ & $\begin{array}{c}0.96 \\
(0.014)\end{array}$ \\
\hline Investment & $\begin{array}{c}6.71 \\
(1.087)\end{array}$ & $\begin{array}{c}0.44 \\
(0.161)\end{array}$ & $\begin{array}{c}0.76 \\
(0.076)\end{array}$ & $\begin{array}{c}6.83 \\
(0.809)\end{array}$ & $\begin{array}{c}0.45 \\
(0.216)\end{array}$ & $\begin{array}{c}0.89 \\
(0.039)\end{array}$ \\
\hline Labor supply & $\begin{array}{c}1.07 \\
(0.178)\end{array}$ & $\begin{array}{c}0.55 \\
(0.097)\end{array}$ & $\begin{array}{c}0.46 \\
(0.198)\end{array}$ & $\begin{array}{c}2.74 \\
(0.322)\end{array}$ & $\begin{array}{c}0.49 \\
(0.208)\end{array}$ & $\begin{array}{c}0.89 \\
(0.034)\end{array}$ \\
\hline lmport & $\begin{array}{c}8.39 \\
(1.872)\end{array}$ & $\begin{array}{c}-0.04 \\
\langle 0.103\}\end{array}$ & $\begin{array}{c}0.47 \\
(0.169)\end{array}$ & $\begin{array}{c}5.70 \\
(0.680)\end{array}$ & $\begin{array}{c}0.42 \\
(0.216)\end{array}$ & $\begin{array}{c}0.99 \\
(0.005)\end{array}$ \\
\hline Intercst paymerits & $\begin{array}{c}15.26 \\
(2.566)\end{array}$ & $\begin{array}{c}0.40 \\
(0.138)\end{array}$ & $\begin{array}{c}0.44 \\
(0.169)\end{array}$ & $\begin{array}{c}6.41 \\
(0.731)\end{array}$ & $\begin{array}{c}0.84 \\
(0.151)\end{array}$ & $\begin{array}{c}0.03 \\
(0.163)\end{array}$ \\
\hline $\begin{array}{c}\text { Tradc balance } \\
\text { (TB/GDP) }\end{array}$ & $\begin{array}{c}1.00 \\
(0.172)\end{array}$ & $\begin{array}{c}0.14 \\
(0.171)\end{array}$ & $\begin{array}{c}0.08 \\
(0.133)\end{array}$ & $\begin{array}{c}1.59 \\
(0.188)\end{array}$ & $\begin{array}{c}0.16 \\
(0.236)\end{array}$ & $\begin{array}{c}0.74 \\
(0.075)\end{array}$ \\
\hline $\begin{array}{c}\text { Terms of tradc } \\
\text { (TOOT) }\end{array}$ & $\begin{array}{c}5.43 \\
(0.897)\end{array}$ & $\begin{array}{c}0.43 \\
(0.175)\end{array}$ & $\begin{array}{c}0.76 \\
(0.147)\end{array}$ & $\begin{array}{c}3 .(31 \\
(0.359)\end{array}$ & $\begin{array}{c}0.40 \\
(0.219)\end{array}$ & $\begin{array}{c}0.70 \\
(0.085)\end{array}$ \\
\hline
\end{tabular}

NOTES: The Anstralian data are obtained from ABS, divided by the 15+ population, deflated by impore prices (See Mendoza 1995 and Senhadji 1998), logged and detrended by a Hodrick-Prescott filter

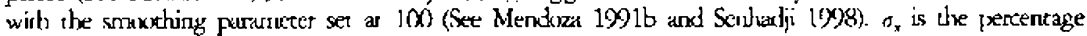
scandard deviation, $\rho_{x z, x t-1}$ is the first-order autcorrelation, and $\rho_{x, 1}$ itzy is the contemporaneous corrclation with GDP. The values in the parenthesis represcit the standard deviations estimated by GMM (Genetalized Method of Moment) using the Hansen-Heaton-Ogaki gauss program. The model statistics are based on the sample average values of 100 simulations of 36 years. We generated historics of 169 observations and truncated the first 133 nbservations so that the resules do not depend on the initial condition of the state variables of the model (Ambler, Cardia and Zimmermann forthcomingl. 
0.39 in the real data and the berxhmark economy, respectively. Morcover, the autocorrelations of investment $(0.44,0.45)$, labor supply $(0.55,0.49)$, trade balance $(0.14,0.16)$ and terms of trade $(0.43,0.40)$ prove that the benchmark economy replicates fairly well the real economy. The correlations of macroeconomic variables with output mimic well the benchmark economy in consumption $(0.95,0.96)$, investment $(0.76,0.89)$ and terms of trade $(0.76,0.70)$. In general, the benchmark economy replicates the distinguished features of a real economy. Our model especially shows a better feature in terms of explaining the persistence of fluctuation as compared to other real business cycle models.

\section{Sensitivity Analysis}

Table 3 presents the findings of simulation that raise cvery parameter by $5 \%$. In general, the macroeconomic variables of the benchmark model are stable to the change of parameters. Autocorrelations are relatively more sensitive to the change of parameters than standard deviation and correlations with output. Investment (from 6.49 to 6.977 is most sensitive to the change of parameter in standard deviation. The intertemporal elasticity of substitution in labor supply affects relatively strongly investment.

Table 3. Sensitivity ANai.ysis

\begin{tabular}{|c|c|c|c|c|c|c|c|c|c|c|c|c|}
\hline & \multicolumn{4}{|c|}{ Volatility } & \multicolumn{4}{|c|}{$\begin{array}{c}\text { First-order } \\
\text { serial correlation }\end{array}$} & \multicolumn{4}{|c|}{ Corrclation with output } \\
\hline & $C$ & 1 & $\mathbf{M}$ & $\mathrm{TB} / X$ & $C$ & 1 & M & $\mathrm{TB} / \mathrm{Y}$ & C & 1 & M & $\mathrm{TB} / \mathrm{Y}$ \\
\hline $\begin{array}{l}\text { Baseline } \\
\text { Model }\end{array}$ & 3.76 & 6.83 & 5.70 & 1.59 & 0.39 & 0.45 & 0.42 & 0.16 & 0.96 & 0.89 & 0.99 & 0.74 \\
\hline$\gamma$ & 3.81 & 6.97 & 5.71 & 1.55 & 0.39 & 0.46 & 0.43 & 0.14 & 0.96 & 0.90 & 0.99 & 0.72 \\
\hline$\theta$ & 3.59 & 6.51 & 5.74 & 1.58 & 0.45 & 0.52 & 0.43 & 0.17 & 0.93 & 0.88 & 0.93 & 0.73 \\
\hline $\mathrm{r}^{*}$ & 3.75 & 6.87 & 5.69 & 1.57 & 0.39 & 0.45 & 0.42 & 0.27 & 0.95 & 0.89 & 0.99 & 0.80 \\
\hline$\delta_{1}$ & 3.77 & 6.78 & 5.71 & 1.63 & 0.39 & 0.45 & 0.43 & -0.04 & 0.96 & 0.89 & 0.99 & 0.66 \\
\hline$\delta_{2}$ & 3.77 & 6.71 & 5.69 & 1.58 & 0.39 & 0.44 & 0.42 & 0.19 & 0.95 & 0.89 & 0.99 & 0.76 \\
\hline$\phi_{\perp}$ & 3.75 & 6.80 & 5.69 & 1.55 & 0.39 & 0.46 & 0.43 & 0.31 & 0.96 & 0.89 & 0.99 & 0.82 \\
\hline$\phi_{z}$ & 3.74 & 6.49 & 5.68 & 1.69 & 0.39 & 0.45 & 0.43 & -0.15 & 0.96 & 0.89 & 0.99 & 0.63 \\
\hline$\omega_{1}$ & 3.78 & 6.77 & 5.66 & 1.58 & 0.38 & 0.45 & 0.42 & 0.20 & 0.95 & 0.89 & 0.99 & 0.77 \\
\hline$\pi_{1}$ & 3.81 & 6.80 & 5.73 & 1.59 & 0.38 & 0.44 & 0.42 & 0.19 & 0.95 & 0.89 & 0.98 & 0.76 \\
\hline$\rho_{i}$ & 3.76 & 6.80 & 5.70 & 1.59 & 0.39 & 0.45 & 0.42 & 0.09 & 0.96 & 0.89 & 0.99 & 0.72 \\
\hline$\lambda$ & 3.71 & 6.69 & 5.69 & 1.58 & 0.39 & 0.46 & 0.42 & 0.04 & 0.96 & $0 . \% 0$ & 0.98 & 0.70 \\
\hline
\end{tabular}

NOTE: Basclinc model with each of the following parameters increased by $5 \%$ 
The adjustment cost of the non-manufacturing sector has a strong effect on the standard deviation of trade balance. Trade balance is most sensitive to the change of parameters in autocorrelation. Trade balance is also most affected by the change of the adjustment cost of the non-manufacturing sector. Consumption, investment and imports are very stable to the change of parameters in autocorrelation. However, consumption and investment are affected relatively strongly by the change of the intertemporal elasticity of substitution in labor supply, which indicates that labor supply has a role in connecting sectors, thereby allowing spillover effects across sectors. The parameter $(\rho)$, which causes a spillover effect, does not have a significant effect on major macroeconomic variables.

\section{Impulse Response Analysis}

This section presents the impulse response of economic variables to the shocks of sectoral productions and terms of trade shock. Impulse response analysis is useful to assess the dynamic characterization of an economic system and to measure the magnitude of the effects of economic variables to the shock.

Figure 1 shows the impulse response of each variable to $1 \%$ positive shocks of sectoral productivities and the terms of trade. To compare the size of shock effects, Figure 1 shows the effect of each variable to thrce different shocks; namcly, the productivity shocks of both manufacturing and non-manufacturing productions, and the terms of trade shock. The tffect of the productivity shock of the non-manufacturing sector on GDP is sttonger than the effects of the productivity shock of manufacturing production and the terms of trade shock. The effects of the productivity shock of manufacturing production and terms of trade shock on GDP are similar in magnitude. For the $1 \%$ positive shocks, GDP increases, and then converges to an equilibrium path. The effect of productivity shock of non-manufacturing production on consumption is greater than the effects of the productivity shock of manufacturing production and the terms of trade shock, and is similar to output. Interestingly, the terms of tradc shock have a stronger effect on consumption than the productivity shock of manufacturing production. The effects of the shocks on investment and imports are in the order of the productivity shock of non-manufacturing pruduction, terms of tracie shock and the productivity shock of manufacturing production, and are different from the effect on consumption. The increase of productivity in non-manufacturing production causes the decline of domestic price, and may decrease imports. However, if the quantitative effect overwhelms the price effect likely to occur in our model, the imports rise. Moreover, in our model, because the exugenous terms of trade are assumed, the quantitative effects have a dominant role on imports. A distinguishing feature is that the effect of the productivity shock of non-manufacturing production on investment is relatively higher than on GDP, consumption and imports, in comparison with the effects of the productivity shock of manufacturing production and the terms of trade shock. 
Figure 1. Implise Response to Sectoral Proiductivity Shocks and Terms of Trade Shock

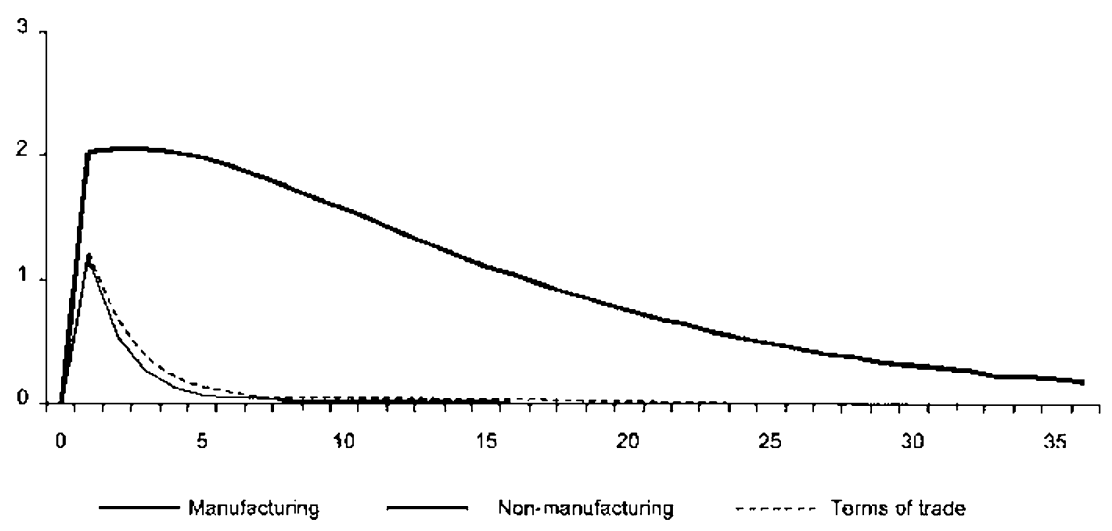

(a) GDP

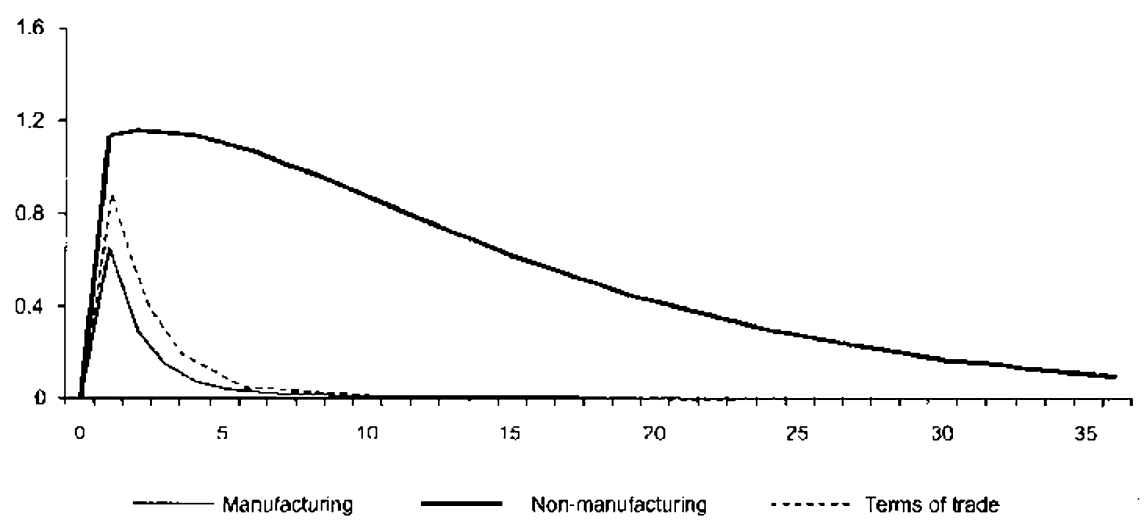

(b) Consumption

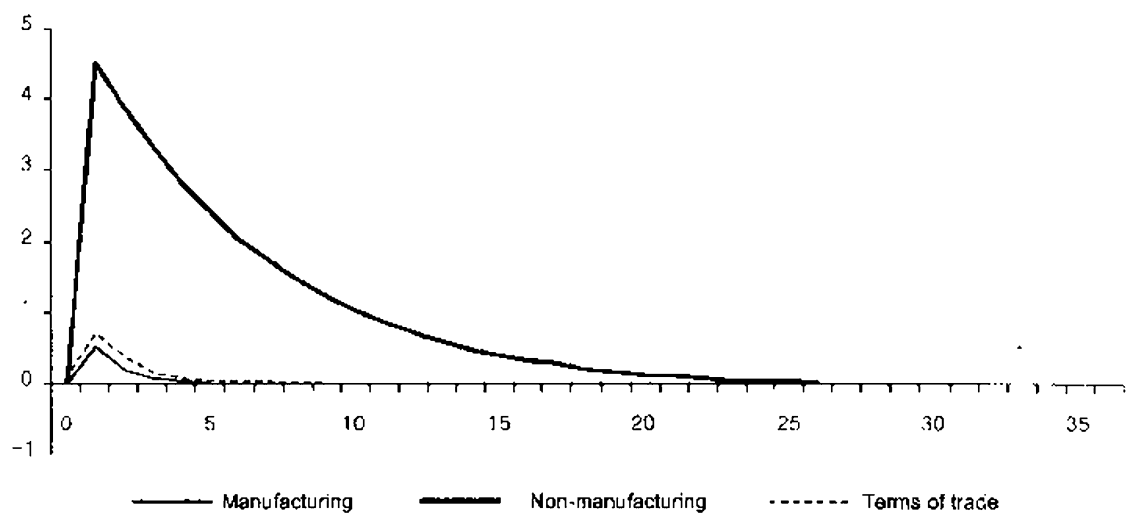

(c) Investment 
Figutre 1. (CON'D)

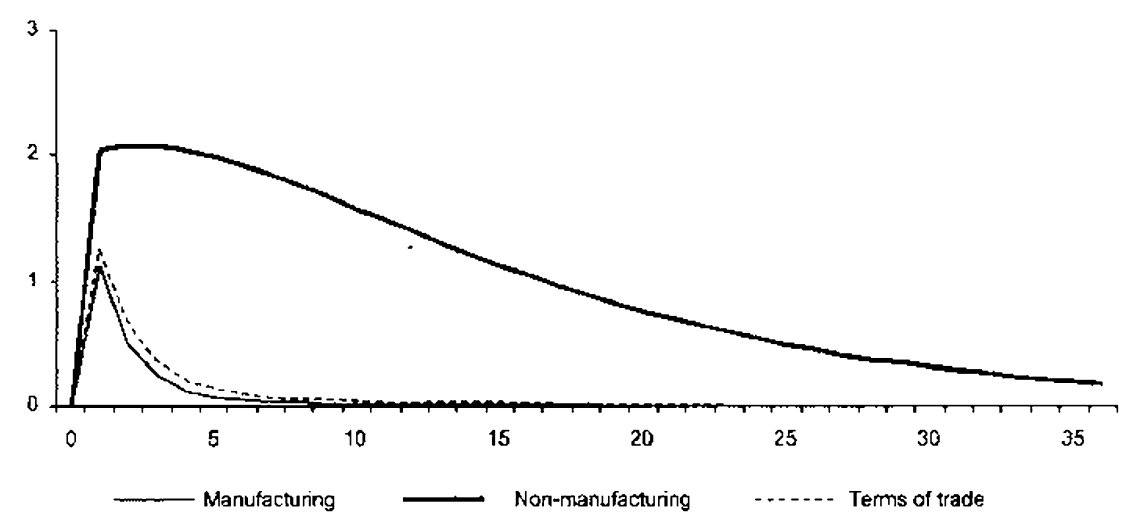

(d) Imports

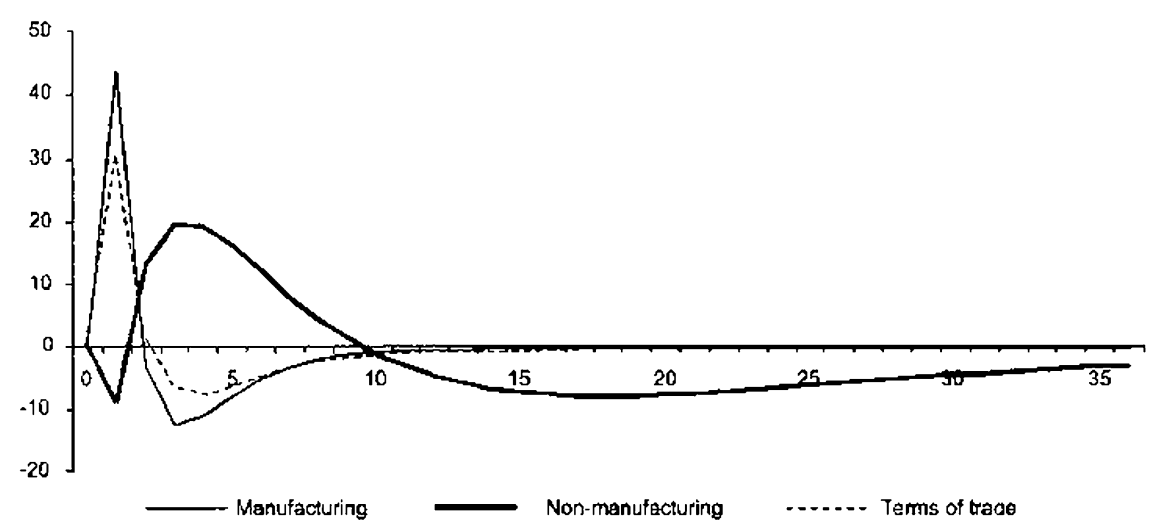

(e) Trade balance

A positive productivity shock in manufacturing production and positive terms of trade shock increase trade balance. On the other hand, a positive productivity shock in non-manufacturing production decreases trade balance, indicating that the shock increases imports more than exports. A positive productivity shock in manufacturing production has a stronger effect on trade balance than on terms of trade shock, different from other macroeconomic variables. In other words, the increase of productivity in manufacturing causes exports to rise, whereas the increase of productivity in non-manufacturing causes impors to increase. In the Australian economy, the portion of non-manufacturing productions is over $80 \%$ of industry productions. Accordingly, the productivity shock of non-manufacturing production has stronger effects on macroeconomic variables than the produccivity shock of manufacturing production and terms of trade. Moreover, it is an interesting feature that the terms of trade shock have a stronger effect than the productivity of manufacturing production on economic variables. 


\section{CONCLUDING REMARKS}

Our paper analyze an international real business cycle model of a small open economy. Under the assumption that the model of the economy produces two goods, and has two sectoral productivity shocks and terms of trade shock, our paper investigates the central issue of how economic variables fluctuate in response to shocks.

We conducted the quantitative analysis on the effects of sectoral productivity shocks and the terms of trade shock using the Australian daca. The model cconomy replicatcs fairly well the teal economy in properties of second moments. The finding of sensitivity analysis supports the notion that the model is stable except for trade balance. The autocorrelation of trade balance is relatively sensitive to the change of adjustment cost in non-manufacturing production, which indicates the strong connection between the non-manufacturing sector and the foreign sector. The change of elasticity of substitution in intermediate goods production, which shows spillover effects between sectors, has a small effect on manufacturing. This implies that sectoral transmission effects are very stable. From impulse response analysis, the productivity of non-manufacturing production has a dominant role in the business cycle of the Australian economy. The effect is stronger than the productivity shock of manufacturing production and the terms of trade shock. Moreover, the strong effect increases imports more than exports, and thus declines trade balance temporally, while the productivity shoxk of manufacturing production increases exports more than imports.

\section{REFERENCES}

Ambler, S., Cardia, E. and Zimmermann, C., forthcoming. International Transmission of the Business Cycle in a Multi-Sectoral Model. European Economic Review.

Backus, D., Kehoe, P.J. and Kydland, F.E. 1992. International Real Business Cycles. Journal of Political Economy 100: 745-75.

Backus, D., Kehoe, P.J. and Kydland, F.E. 1995. International Real Business Cycles: Theory vis Evidence. Princeton, NJ: Princeton Lniversity Press.

Canova, F, and Ubide, A. 1997. International Business Cycles, Financial Markets and Household Production. Finance and Banking Discussion Paper Series 27, Univeriitat Pompeu Fabra.

Costello, D. and Praschnick, J. 1993. Intermediate Goods and the Transmission of International Business Cycles. University of Western Ontario. Mimeo.

Christiano, L. J. 1998. Solving Dynamic Equilibrium Models by a Method of Undetermined Coefficients. NBER Technical Working Paper 225.

Devereux, M.B, Gregory, A.W. and Smith, G.W. 1992. Realistic Cross-Country Consumption Correlations in a Two-Country, Equilibrium Business Cycle Model. Joumal of International Money and Finane 11: 3-16.

IIcad, A. 1997. Aggregate Fluctuations with National and International Returns to Scale. Queen's University. Mimeo. 
Kouparitsas, M. 1995. North-South Financial Integration and Business Cycles. Working Paper 96-10, Federal Reserve Bank of Chicago.

Long, J.B., Plosser, C.I. 1983. Real Business Cycles. Joumal of Political Ecnnomy 91: 39-69.

Mendoza, E.G. 1991a. Capital Control and the Gains from Trade in a Business Cycle Model of a Small Open Economy. IMF Staff Pater 38: 480-505.

Mendoza, E.G. 1991b. Real Business Cycle in a Small Open Economy. American Economic Review 81: 797-818.

Mendoza, E.G. 1995. The Terms of Trade, the Real Exchange, and Economic Fluktuation, International Economic Review 36: 101-37.

Senhadji, A.S. 1998. Dynamics of the Trade Balance and the Terms of Trade in LDCs: the S-Curve. Journal of International Economicr 46: 105-31.

Schmitt-Grohé, S. 1998. The International Transmission of Economic Fluctuations: Effects of U.S. Business Cycles on the Canadian Economy. Journal of International Economics 4.4: $257-87$.

Stockman, A.C. and Tesar, L.L. 1995. Tastes and Technology in a Two-Country Model of the Business Cycle: Explaining lnternational Co-movements. American Economic Review 85: 168-85.

Whalley, J. 1995. Tradc Libcralization among Major World Trading Areas. Cambridge, MA: MIT press.

7immermann, C. 1999. International Business Cycles and Exchange Rates. Review of International Econmics 7: 682-98.

\section{APPENDIX: DATA}

The Australian data are obtained from ABS (Australian Bureau Statistics). All series are composed of yearly observations from 1965 to 1999 . All variables except for labor supply are divided by import price. Output: nominal GDP. Comszmption: noninal private final consumption expenditure. Investment: nominal gross capital formation. Labor supply: the number of non-farm civilian wage and salary carners $x$ index of hours worked. Population: civilian population aged 15 years and over. Interest payments: (nominal investment income to overseas - nominal investment income from overseas). Import: nominal imports of goods. Trade balance: (nominal exports of goods - nominal imports of goods) $\div$ nominal GDP. Terms of trade: implicit price index of goods export $\div$ implicir price index of goods import. 


\section{ENDNOTES}

1 The quantity anomaly means that in the data, cross-country correlations of output are generally higher than cross-country correlations. The price anomaly implies that general equilibrium models do not pencrate fluctuations in terns of trade as large as those cobserved in the data.

2 Positive termis of trade sliock cun be caused by business dowinturn in the forcign sector. Ilowever, it our paper, it is assumed that the terms of trade shocks are mainly caused by che produrcivity shorks in the foreign sector.

3 In the production of sectoral goods, CES production function is two complicate to teal with four production factors such as labour, capital, intermediate goods and import goods. On the other hand the final good production function has an an aggregating feature which can mix two sectoral goods, and thus CES function is suitable for final good production.

"The business cycle model, in pitich exports and imports are incorporated, should include the concept of exchange rate. llowever, we incorporate the terms of trade instead of exchange rate into our model such as Senhadj (1998) and Schmitt-Grohé (1998). It is assumed that the terms of trade include the concept of exchange rate becatuse the change of exchange rate has intlucnce on the terms of tradc.

"Mendora (1995) assumes that importable good price is the same as capital good price. In our model, we follow Mendoz's assumptiorl.

6 It should be noted that $Y_{1}$ is not gross domestic proxluct but $\varepsilon_{1} Y_{t}$ IM, is gross domestic proxluct. In orher words, this implies that import goods are used directly for istermediare good production, but indirectly for consumption and investment.

? These values are obtained from the national account data by using the average ratios of sectoral investments to sectoral capital stocks. 